\title{
Steroid hormone receptors and their clinical significance in cancer
}

\author{
R I Nicholson, R A McClelland, J M W Gee
}

\section{Introduction}

Although all cells within the body are exposed to steroid hormones, their physiological actions are limited to those tissues which contain intracellular binding proteins, termed receptors. These proteins specifically bind the individual classes of steroid hormones with high affinity and transmit the steroid signal to sensitive genes located throughout the chromatin. The type of response subsequently induced is dependent on both the developmental stage and differentiation status of the target tissue, but may involve the control of such diverse end points as cell proliferation, cell death, secretory activity, and cellular mobility. Importantly, the ability of steroid hormones to influence these characteristics is retained in many disease states, notably in certain cancers originating in steroid hormone sensitive tissues including carcinomas of the breast, ${ }^{1}$ genital tract, ${ }^{23}$ gastrointestinal tract, ${ }^{4}$ pancreas, ${ }^{5}$ lung, ${ }^{6}$ and also intracranial tumours. ${ }^{7}$ This has been harnessed therapeutically, with drugs which modify the cellular levels or actions of steroid hormones being commonly used in the treatment of breast, endometrial and prostate cancer. ${ }^{89}$ These tumours frequently retain steroid hormone receptors and their measurement is currently used diagnostically in several centres to identify potential endocrine responsiveness.

As steroid sensitive cancers are relatively common and as cellular transitions associated with the loss of their hormone sensitivity invariably worsen the prognosis for a patient, considerable effort has been afforded to their study. The examination of steroid hormone receptors is pivotal to our understanding of endocrine sensitivity and therefore the current article attempts to summarise our present knowledge of these proteins specifically in those areas of cancer biology which we hope are of particular interest to the pathologist.

\section{Molecular aspects of steroid hormone receptors}

The past decade has seen a remarkable increase in our knowledge of the structure and function of steroid hormone receptors. This has occurred through the isolation and sequence analysis of recombinant DNA clones for the individual receptors. It is now established that the receptor proteins from each of the five classes of steroid hormones, notably oestrogens (ER) ${ }^{10}$ and progestins (PR), ${ }^{10}$ androgens (AR), glucocorticoids (GR), ${ }^{11} 12$ and mineralocorticoids, as well as the receptors for thyroid hormone, ${ }^{13}$ 1,25-dihydroxy vitamin D3 (VDR), ${ }^{14}$ retinoids $(\alpha, \beta$ and $\gamma)$ and so called "orphan" receptors, ${ }^{10}$ which do not have recognised physiological ligands as yet (including HNF-4, ${ }^{15}$ COUP, ${ }^{16}$ Rev-erb A-alpha, ${ }^{17}$ Nur77, ${ }^{18}$ NGFI-B, ${ }^{19}$ TR $3,{ }^{20}$ retinoid $\mathrm{X}$ receptor, ${ }^{21} \mathrm{P}-450$ inducers, ${ }^{11}$ and the DHR3/MHR3 proteins ${ }^{22}$ ), show marked conservation of structure and contain various functional domains, including those for ligand and DNA binding. ${ }^{2324}$ In each instance the steroid receptors act as ligand inducible nuclear transcription factors, with interactions between activated receptors and hormone response elements (HRE) on the DNA directly modifying gene expression. ${ }^{12-25}$ Although some differences exist with respect to the organisation and initial cellular localisation of the individual classes of steroid hormone receptors, ${ }^{12}$ they all ultimately act to stimulate or repress mRNA production from sensitive genes, leading to changes in protein synthesis and finally cellular function. ${ }^{23-25}$ However, it has become increasingly evident that steroid hormone receptors represent only part of the transcriptional apparatus involved in the regulation of responsive genes and that they act in concert with other inducers or suppressors of gene expression. ${ }^{1026}$ Thus, hormonally directed genes can show responsiveness to peptide growth factors. This is exemplified by the oestrogen regulated gene $\mathrm{pS} 2$ (pNR2) which has been shown to be sensitive to the growth factors transforming growth factor $\alpha$ (TGF $\alpha$ ), epidermal growth factor and also insulin-like growth factor $\mathrm{I}^{27} \mathrm{~A}$ further example is seen with $\mathrm{PR}$, traditionally an oestrogen regulated protein, which can also be activated through dopaminergic and adrenergic signalling mechanisms. ${ }^{28}$ Such interactions raise interesting questions concerning the role of cross-talk between steroid hormone receptors and other signalling pathways in the regulation of transcriptional efficiency, constitutive action of the receptor and acquisition of endocrine resistance. A knowledge of such pathways may provide previously unrecognised opportunities for tumour therapy. ${ }^{10}$

\section{Methods of detection}

The observation that hormone sensitive tissues were able to take up and retain radiolabelled steroids against a concentration gradient of the steroid ${ }^{26}$ lead to the initial discovery of steroid hormone receptors. This property was subsequently exploited in "test tube" biochemical assays, notably dextran coated charcoal (DCC) adsorption ligand binding assays $\left(\mathrm{LBA}^{126}\right)$, generating information on the concentration of 
steroid hormone receptors within solubilised tissue extracts, together with their binding affinity constants. Unfortunately, the ease of performing these assays and also their subsequent clinical value varies between tumour types and surgical procedures used. Thus, while breast and endometrial cancer samples are relatively accessible enabling valuable data to be readily obtained, it is often essential to remove prostate tumour specimens by transurethral sectioning, a procedure which generates elevated temperatures and consequently is potentially damaging to any receptor proteins. ${ }^{26}$ Furthermore, the assays are also influenced by both the cellularity of the cancer and the content and associated steroid hormone receptor status of normal or benign tissue. These factors may contribute towards falsely negative or positive receptor results.

More recently developed methodologies rely on direct antigen recognition rather than steroid binding activity, utilising monoclonal antibodies $^{29}$ specific for the various steroid receptors in both enzyme immunoassays (for example, oestrogen receptor enzyme immunoassay $(\text { ER-EIA })^{30}$ ) and also immunocytochemistry (for example, oestrogen receptor immunocytochemical assay (ER-ICA) ${ }^{12631}$ ). The value of the latter technique lies in its relevance to histological sections and thus the procedure has numerous advantages for the pathologist. Steroid receptors can be directly visualised by a colour reaction within individual cell types. This is not possible using biochemical methods, which require that tissues should be homogenised before being assayed, with an associated loss of information regarding heterogeneity of receptor expression in normal, benign and malignant components of the tumour. ${ }^{26}$ Immunohistochemical assays can also be applied to biopsied or cytological material $^{1}$ and thus have the ability to generate accurate results on low cellular tumours. Furthermore, the technique allows several different proteins to be investigated on the multiple sections obtained from each tissue sample, readily permitting the construction of a larger biological profile of the tumour. Scoring of nuclear heterogeneity after immunocytochemical staining is possible either manually or using an image analyzer, both methodologies correlating with each other when carried out by experienced workers. ${ }^{32}$ Manual assessment involves the construction of a $\mathrm{H}$ score ${ }^{33}$ which takes into account both the percentage positivity and staining intensity, while image analyzers can be used to assess the percentage of nuclear area immunopositivity. ${ }^{32}$ In breast cancers the use of cut off values ${ }^{32}$ aids the examination of relations between the degree of ER/PR immunostaining and response to endocrine therapies. ${ }^{34}$ Intra- and interlaboratory studies $^{35}$ monitoring immunocytochemical performance and also external quality assurance (QA) schemes for steroid hormone receptor immunocytochemistry are finally emerging. The UK Steroid Receptor Quality Assessment Group has recently been established, spear-headed by Dr R Leake (Department of Biochemistry, University of
Glasgow), providing new workers with vital information regarding steroid receptor QA materials, QA schemes as well as a reference directory of expert laboratories currently engaged in such assays.

Early immunocytochemical studies using antibodies directed against ER (for example, $\mathrm{H} 222$ antibody, available in the ER-ICA kit ${ }^{31}$ from Abbott Diagnostics, North Chicago, Illinois, USA) showed that the protein is localised exclusively within the epithelial cell nuclei in suitably fixed cryosections ${ }^{31}$ (that is, frozen specimens stored at $-70^{\circ} \mathrm{C}$, sectioned and fixed for 10 to 15 minutes in $3.7 \%$ formaldehyde/phosphate buffered saline at room temperature; post-fixed in methanol (five minutes) and acetone (three minutes) at $-20^{\circ} \mathrm{C}$ ) of normal and cancerous genital tract, breast, pituitary, and liver. This observation was at odds with the previously held view of this receptor as a cytosolic protein which was subsequently translocated to the nucleus following its activation by oestrogens. It is now believed that, with the exception of glucocorticoid receptors, each class of steroid hormone receptor resides predominantly in the nuclei of steroid sensitive cells. ${ }^{1}$

Using such antibodies, ER (H222 and 1D5 (Dako, High Wycombe, UK)) and PR may now also be reliably localised in $10 \%$ buffered formalin fixed (exposed to formalin for no longer than 24 hours as prolonged fixation results both in decreased receptor immunoreactivity and in the appearance of non-specific cytoplasmic staining), paraffin wax embedded material following the re-exposure of masked antigenic determinants by controlled protease digestion of the tissue sections ${ }^{36}$ or microwave treatment. $^{37}$ These procedures maintain excellent tissue preservation, and thus accurate receptor determinations can be made in the invasive component of archival tumours, as well as within small, early cancers which are usually processed entirely as formalin fixed, paraffin wax embedded material.

The cloning of the steroid receptor genes and the generation of specific CDNA and oligonucleotide probes has allowed northern hybridisation analysis to be applied to tumour extracts. However, this procedure, while semiquantifiable, is subject to many of the problems described for steroid receptor biochemical assays which utilise tumour lysates. Fortunately, several groups have begun to use in situ hybridisation technologies to study hormone receptor mRNA levels in histological sections. Indeed, both isotopic and non-isotopic (notably digoxigenin) probe labelling procedures can now be used successfully to study the cellular expression of steroid receptor mRNA within frozen and paraffin wax embedded tumour material. ${ }^{3839}$ Although in situ hybridisation is often less amenable to routine use than immunohistochemistry, a recent study ${ }^{38}$ has illustrated its potential value in understanding defects in the steroid receptor transcription/translation pathway. The exquisite sensitivity of this technique has revealed that more mRNA positive results can be recorded for ER than for the resultant protein, ${ }^{38}$ 
implying significant post-transcriptional regulation of ER mRNA, assuming that any negativity recorded for the receptor protein is genuine and not merely the result of poor assay sensitivity.

\section{Steroid hormone receptor expression in the breast}

Steroid hormones, notably oestrogens, are of central importance in growth regulation of the breast. ${ }^{40}$ This requirement is often maintained in the various disease states, including neoplasia. Receptors for the steroid hormones oestrogen and progesterone can thus be demonstrated immunocytochemically in the normal mammary luminal epithelium, but staining is usually sparse ( $7 \%$ of cells) and largely confined to the lobular elements in the premenopausal breast. ${ }^{141}$ This is paradoxical as the mammary parenchyma is usually regarded as exquisitely steroid hormone sensitive, suggesting that such ER negativity should perhaps be viewed with caution. It may merely represent the limits of detection of the assay used or may indicate cellular quiescence. ${ }^{4142}$ ER concentrations in the breast are suppressed at ovulation when there is a surge of oestrogens in premenopausal women so that the ER concentrations are lowest during the luteal phase. ${ }^{1}$ This sharply contrasts with $P R$, which is under regulation by both oestrogen and progesterone and is relatively constant throughout the cycle. ${ }^{4344}$

Steroid hormone receptors are largely maintained in benign breast conditions, ${ }^{145}$ while elevated expression is often associated with breast neoplasia. ${ }^{126}$ Heterogeneity of expression is marked both between patients and within an individual tumour. ${ }^{126}$ Approximately $70 \%$ of primary breast cancers are ER positive while $50 \%$ are $P R$ positive, and the proportion of ER positive tumours increases with age. ${ }^{142}$ ER positive tumours are more likely to spread to bone, while ER negative tumours often metastasise to the liver, brain and regional lymph nodes. ${ }^{146}$ The measurement of ER and PR concentrations in breast cancer specimens is of therapeutic value, providing a means of preselecting patients for various endocrine treatments (primarily antioestrogens), with approximately $75 \%$ of advanced breast cancer patients with tumours positive for ER and PR achieving favourable clinical remission. ${ }^{12647}$ This compares with only $5-10 \%$ of patients with steroid receptor negative disease showing an objective response. ${ }^{26}$ Tumours containing higher steroid receptor concentrations are more likely to respond than those with reduced concentrations. ${ }^{126} \mathrm{PR}$ has been reported to be an independent predictive factor for response to the antioestrogen tamoxifen ${ }^{48}$ and the predictability of response is reported to be increased to $90 \%$ by measuring in vivo induction of this receptor resultant from the partial agonistic activity shown by tamoxifen acting via an intact ER mechanism. ${ }^{49}$ Such receptor assays also provide prognostically useful information. The presence of ER has been correlated with a series of favourable prognostic characteristics, including a well differentiated histology, low nuclear grade, low cellular proliferation, prominent elastosis, slight or absent lymphocytic infiltration, and minimal tumour necrosis. ${ }^{126}$ For the first five to 10 years after primary surgery, patients with ER rich tumours have a more favourable prognosis that those with receptor negative disease. ${ }^{2650} \mathrm{Un}$ fortunately, however, with a longer follow up time and in the absence of adjuvant endocrine treatment, the disease free intervals converge. ${ }^{1}$ In adjuvant endocrine trials greatest benefit is predictably observed in those women with ER/ PR rich cancers. ${ }^{12651}$

In the UK the use of these assays to tailor therapy to the tumour characteristics of individual patients is only sparingly applied and a more pragmatic approach is frequently undertaken which uses the relatively non-toxic antioestrogenic drug tamoxifen to assess endocrine responsiveness clinically. ${ }^{42}$ This approach has arisen primarily from inaccuracies observed in the prediction of clinical response by steroid receptor assessment. ${ }^{52}$ An immunohistochemical approach to steroid hormone receptor measurements, however, facilitates the construction of a broader biological view of the tumour and demonstrates that further elements other than steroid receptors can influence and correlate closely with clinical response to endocrine treatments. Thus, the increased expression of various peptide growth factors (notably $\mathrm{TGF} \alpha^{53}$ ) and their receptors $\left(\mathrm{EGFR}^{545}\right.$ ), proto-oncogene products (c-erbB2 $2^{54}$ ) and also markers indicative of cell proliferative activity $\left(\mathrm{Ki} 67^{54}\right)$ have been associated with loss of endocrine sensitivity ${ }^{40}$ despite positivity for steroid receptors often being maintained.

It is also possible that further anomalies could arise in the prediction of clinical response to endocrine therapy using steroid receptor profiles if these receptors were occasionally nonfunctional. An interesting approach to the identification of functionality of steroid receptors has been to measure their gene products. It is fair to say, however, that the identification of target genes involved in the hormonal control of cell behaviour has lagged behind the analysis of the structure and function of these receptors as transcription factors. Most progress has been made with oestrogen regulated genes, with several groups reporting successful cloning strategies. $\mathrm{PR}^{52}, \mathrm{pS} 2^{56}, \mathrm{pLIV} 1,{ }^{57}$ and cathepsin $\mathrm{D}^{58}$ have been described as oestrogen regulated proteins, with all but cathepsin D showing enrichment within ER positive disease. ${ }^{56579}$ Where studied, the expression of oestrogen regulated gene products in clinical breast cancer, although often associated with endocrine responsiveness and invariably also having prognostic value, ${ }^{56}$ does not add substantially to the information that may be gained from ER measurements alone. Where the expression of several oestrogen regulated genes has been studied within the breast cancer population, it is evident that they are not always co-expressed in ER positive disease. Their differential expression may reflect differing biological behaviour patterns of the tumours, with-for 
example, ER/pLIV1 dual positivity significantly correlating with lymph node involvement in contrast to $\mathrm{ER} / \mathrm{pS} 2$ positivity. ${ }^{60}$

Potentially, the control of such activities may reside in variations in the promoters of individual genes or in the sensitivity of the promoters to mutations in the ER. Possibly the most important value of polymerase chain reaction (PCR) amplification technology in steroid receptor determination is the highly sensitive detection of rare defects in the steroid receptor genes and their mRNAs. ${ }^{61}$ An expanding number of ER mutations have now been documented, including those which can lead to either a loss of either the hormone or DNA binding domain. Several mutations have been successfully identified, albeit at a low frequency, in human breast cancers in vivo. ${ }^{6263}$ These frequently occur through frame shift/ termination mutations in the ER gene, generating what has been appropriately described by the group from Texas as "outlaw receptors". ${ }^{62}$ The functional significance of these mutants has been demonstrated by Fuqua et $a l^{64}$ who showed that ER lacking exon 5, encoding the hormone binding domain, constitutively activated transcription of a normally oestrogen dependent gene construct in yeast cells. These observations show that a mutant ER could potentially dramatically affect oestrogen responsiveness of a cancer by acting as a constitutive activator of gene expression even in the absence of oestrogens, ${ }^{62}$ and thus such mutations could potentially be of some importance in controlling breast cancer growth observed following the acquisition of hormone/ antihormone resistance. ${ }^{63}$ Similarly, mutations in the DNA binding domain could alter the DNA specificity of the receptor leading to promiscuous activation of genes not normally responsive to oestrogens, or result in the loss of DNA binding. Most striking is the recent observation showing that ER variants can interfere with the function of the wild-type receptor, ${ }^{6264}$ either by forming inactive heterodimer complexes or by binding to the oestrogen response element (ERE) in a redundant conformation. These observations suggest that mutations can act in a rather insidious way as dominant negative oncogenes. ${ }^{62}$

\section{Steroid hormone receptor expression in} the female genital tract

The female genital system, like the breast, is a prime target organ for the steroid hormones progesterone and oestrogen. Steroid receptors are present throughout the reproductive tract in the ovaries, endometrium, cervix, and vulva. ${ }^{2}$ Steroid hormone dependence is particularly marked in the endometrium, which in the premenopausal woman contains glandular epithelial cells (and to a lesser extent stroma) with both ER and PR. ${ }^{265}$ In common with the normal breast, receptors in the endometrium vary noticeably in concentration with the fluctuations that occur in their respective ligands throughout the menstrual cycle. ${ }^{265}$ Thus, ER peaks in the proliferative phase of the cycle when the circulating concentrations of pro- gesterone are low, and subsequently falls under the inhibition of rising progesterone during the secretory phase. PR is induced during the proliferative phase by elevated oestrogen concentrations.

As in the breast, steroid hormone receptors are maintained in the female reproductive tract during the process of neoplasia. ${ }^{2}$ Similarly, there is a loss of these receptors in the genital tumour epithelial cells with diminished tumour differentiation and advancement of malignancy. ${ }^{2667}$ Thus, in the endometrium, PR (and to a lesser extent ER) concentrations are inversely related to tumour grade and stage, while they are usually diminished in associated metastases. ${ }^{2266667}$

Although not of established value as yet, steroid receptor analyses look promising for the stratification of endometrial cancer patients for endocrine therapy (primarily progestational agents ${ }^{26}$ ). Thus, $\mathrm{PR}$ is proving to be a particularly valuable index of response to progestin therapy in such tumours. There is an overall response rate of $89 \%$ for PR positive metastatic endometrial adenocarcinomas compared with only $17 \%$ for receptor negative cancers. ${ }^{26} \mathrm{Un}$ fortunately, the therapeutic usefulness of ER is thought to be more limited. ${ }^{26}$ Indeed, in ovarian cancers the concentrations of ER reported are on average lower than those recorded in breast cancers, ${ }^{2}$ and this may explain the overall poor and often conflicting objective response rate of ovarian cancer to antioestrogen therapy.

The assessment of steroid receptors is also potentially of important prognostic value in female genital cancers. ${ }^{2}$ This is most apparent for endometrial cancer, where PR positivity is associated with an increased disease free interval and improved survival. ${ }^{68}$ The usefulness of ER assessment in genital cancers is again more controversial, ${ }^{2669}$ although dual assessment of a high tumour ER and PR content is, however, usually an indicator of longer survival. $^{7071}$

\section{Steroid hormone receptor expression in the male genital tract}

It is known that as with the female, the male reproductive system is also under strict steroid hormone control in both normal and disease states. Thus, the prostate gland contains receptors for androgens (AR) in its secretory epithelia. ${ }^{72}$ In contrast to the breast, however, there have been difficulties in the development of accurate biochemical and immunocytochemical assays for prostatic $\mathrm{AR}^{26}$ although research in this field is now expanding rapidly as antibodies to the receptor become more readily available. ${ }^{73}$ The steroid receptors ER and PR have also been identified in the urothelium of the central prostatic ducts and the prostatic urethra, in the periglandular fibrocytes, smooth muscle cells, interglandular stromal cells, and also associated with the stroma surrounding the ejaculatory ducts and seminal vesicles, although the secretory epithelia are thought to be ER and PR negative. ${ }^{74}$ 
All three of these steroid hormone receptors ${ }^{3}$ have been shown to be more apparent in benign prostatic hyperplasia (BPH), while AR concentrations are usually reduced in carcinomas compared with those seen in $\mathrm{BPH},{ }^{73}$ with an inverse correlation existing between receptor expression and grade. ${ }^{75}$ While the ER and the PR status are of some predictive value in many neoplasms of the female reproductive system and the breast, it is the AR that is of primary importance in prostate carcinoma. Indeed, this forms the rationale for treatment of the disease with antiandrogenic drugs and AR positive tumours usually have a better response to such therapies. ${ }^{26}$ Recent data suggest that the scoring of AR immunostaining intensity rather than percentage positivity ${ }^{76}$ may possibly discriminate good responders.

As seen with ER in the breast, a number of AR mutations have been detected in clinical prostate cancer specimens ${ }^{7778}$ and also within the LNCaP prostate carcinoma cell line. ${ }^{79} \mathrm{Im}$ portantly, the AR mutation in $\mathrm{LNCaP}$ cells greatly influences the specificity of hormone binding, resulting in receptors that have an increased binding affinity for both oestradiol and progesterone, with the antiandrogen hydroxyflutamide acting as an agonist. ${ }^{79}$ Interestingly, Schoenberg $e t a l^{78}$ have identified a mutation in the AR gene in some patients with prostate cancer who also exhibit an agonistic response to flutamide. These data suggest that a knowledge of mutations may be critical in determining appropriate methods of treatment with steroid hormones or antagonists. ${ }^{79}$ In clinical material AR mutations are thought to occur as late events and are thus quite prevalent in advanced disease where they have been linked with the acquisition of androgen insensitivity. ${ }^{77}$

\section{Conclusions}

It is apparent that steroid hormone receptors are of pivotal importance in the control of growth and development of steroid hormone sensitive tissues in their normal and disease states. This has been harnessed therapeutically, with antihormonal drugs, which bind to these receptors thereby competing with endogenous steroid hormones, frequently being used in the treatment of breast, endometrial and prostate cancer. The measurement of steroid receptors is now used in many centres to stratify such patients for the potential hormonal/antihormonal responsiveness of their tumours. This is exemplified in breast cancer, where ER and PR are monitored, but is also of growing importance in genital cancers in both women (PR) and men (AR). It is becoming increasingly obvious that a wider knowledge of the molecular and cellular biology of these receptors in their functional and non-functional forms is an essential prerequisite to the full understanding of pathways of steroid hormone sensitivity and insensitivity. Much of this work could be performed by the pathologist, ${ }^{80}$ with clinical material representing the final testing ground for experimentally derived hypotheses. It is envisaged that involvement of the pathologist in monitoring steroid hormone re- ceptors would ultimately provide data that might be used to aid in selecting primary or adjuvant therapy, evaluating new therapies, estimating prognosis, and assessing outcome. ${ }^{80}$

1 Rayter Z. Steroid receptors in breast cancer. $B r \mathcal{F}$ Surg 1991 ; 78:528-35.

2 Soutter WP, Leake RE. Steroid hormone receptors in gynaecological cancers. In: Bonnar J, ed. Recent advances in obstetrics and gynecology. Vol 15. New York: Churchill Livingstone, 1987:175-94.

3 Mobbs BG, Liu Y. Immunohistochemical localization of progesterone receptor in benign and malignant human prostate. Prostate 1990;16:245-51.

4 Wu CW, Tsay SH, Chang TJ, Chang HM, Hsieh MC, Lui WY, et al. Clinicopathologic comparisons between estrogen receptor-positive and -negative gastric cancers. $f$ Surg Oncol 1992;51:231-5.

5 Ladanyi M, Mulay S, Arseneau J, Bettez P. Estrogen and progesterone receptor determination in the papillary cystic progesterone receptor determination in the papillary cystic and ultrastructural observations. Cancer 1987;60:1604-11.

6 Colley MH, Geppert E, Franklin WA. ImmunoColley MH, Geppert E, Franklin WA. Immuno-
histochemical detection of steroid receptors in a case of pulmonary lymphangioleiomyomatosis. Am $\mathcal{F}$ Surg Patho 1989;13:803-7.

7 Whittle IR, Hawkins RA, Miller JD. Sex hormone receptors in intracranial tumours and normal brain. Eur $\mathcal{F}$ Surg Oncol 1987;13:303-7.

8 Nicholson RI, Walker KJ, Davies P. Hormone agonists and antagonists in the treatment of hormone sensitive breast and prostate cancer. Cancer Surv 1986;5:463-86.

9 Nicholson RI, Manning DL, Gee JMW. New antihormonal approaches to breast cancer therapy. Drugs of Today 1993, 29:363-72.

10 Wakeling AE. Steroid antagonists as nuclear receptor blockers. Cancer Surv 1992;14:71-85.

11 Gustafsson JA, Dahlman-Wright K, Stromstedt PE, Wright T, Carlstedt-Duke J. Structure-function aspects of the glucocorticoid receptor. Int Symp Princess Takamatsu Can cer Res Fund 1990;21:137-55.

12 Gower WR. Mechanism of glucocorticoid action. 7 Fla Med Assoc 1993;80:697-700.

13 Parker MG. Structure and function of nuclear hormone receptors. Semin Cancer Biol 1990;1:81-7.

14 Ozono $\mathrm{K}$, Sone T, Pike JW. The genomic mechanism of action of 1,25-dihydroxyvitamin D3. I Bone Miner Res 1991;6:1021-7.

15 Metzger S, Halaas JL, Breslow JL, Sladek FM. Orphan receptor HNF-4 and bZip protein C/EBP alpha bind to overlapping regions of the apolipoprotein $\mathrm{B}$ gene promoter and synergistically activate transcription. If Biol Chem 1993;268:16831-8

16 Tran P, Zhang XK, Salbert G, Hermann T, Lehmann JM, $P$ fahl $M$. COUP orphan receptors are negative regulator of retinoic acid response pathways. Mol Cell Biol 1992;12. 4666-76.

17 Chawla A, Lazar MA. Induction of Rev-ErbA alpha, an orphan receptor encoded on the opposite strand of the alpha-thyroid hormone receptor gene, during adipocyte differentiation. $\mathcal{F}$ Biol Chem 1993;268:16265-9.

18 Davis IJ, Hazel TG, Chen RH, Blenis J, Lau LF. Functiona domains and phosphorylation of the orphan receptor Nur77. Mol Endocrinol 1993;7:953-64.

19 Fahrner TJ, Carroll SL, Milbrandt J. The NGFI-B protein an inducible member of the thyroid/steroid receptor family, is rapidly modified posttranslationally. Mol Cell Biol 1990, 10:6454-9.

20 Kokontis J, Liao S, Chang C. Transcriptional activation by TR3 receptor, a member of the steroid receptor superfamily. Receptor 1991a;1:261-70.

21 Stopera SA, Bird RP. Nuclear retinoic acid "orphan" receptors: progress towards an understanding of the new complexities in retinoid metabolism. Prog Food Nutr Sci 1991;15:219-30.

22 Koelle MR, Segraves WA, Hogness DS. DHR3: a Drosophila steroid receptor homolog. Proc Natl Acad Sci USA 1992;89:6167-71

23 Fuller PJ. The steroid receptor superfamily: mechanisms of diversity. FASEB f $1992 ; 5: 3092-9$.

24 O'Malley BW, Tsai MJ. Molecular pathways of steroid receptor action. Biol Reprod 1992;46:163-7.

25 Landers JP, Spelsberg TC. New concepts in steroid hormone action: transcription factors, proto-oncogenes, and the cascade model for steroid regulation of gene expression. Crit Rev Eukaryot Gene Expr 1992;2:19-63.

26 Merkel DA, Osborne CK. Use of steroid receptor assays in cancer management. Rev Endocrinol Rel Cancer 1988;30: 5-12.

27 Chalbos D, Philips A, Galtier F, Rochefort H. Synthetic $\mathrm{D}$ messenger ribonucleic acid by growth factors and adenosine $3^{\prime}, 5^{\prime}$-monophosphate in MCF-7 cells. Endocrinology 1993;133:571-6.

28 Power RF, Mani SK, Codina J, Conneely OM, O'Malley BW. Dopaminergic and ligand-independent activation of BW. Dopaminergic and ligand-independent activation
steroid hormone receptors. Science 1991;254:1636-9.

29 King WJ, Greene GL. Monoclonal antibodies localise oestrogen receptor in the nuclei of target cells. Nature 1984; 307:745-7.

30 Leclerq G, Bojar H, Goussard J, Nicholson RI, Pichon MF, Piffanelli A, et al. Abbott monoclonal enzyme immuno- 
assay measurement of estrogen receptors in human breast cancer: a European multicentre study. Cancer Res 1986; 46:4233-6.

31 Walker KJ, Bouzubar N, Robertson J, Ellis IO, Elston CW, Blamey RW, et al. Immunocytochemical localization of estrogen receptor in human breast tissue. Cancer Res 1988; 48:6517-22.

32 McClelland RA, Finlay P, Walker KJ, Nicholson D, Robertson JF, Blamey RW, et al. Automated quantitation of immunocytochemically localized estrogen receptors in human breast cancer. Cancer Res 1990;50:3545-50.

33 McCarty KS Jr, Miller LS, Cox EB, Konrath J, McCarty KS Sr. Oestrogen receptor analysis: correlation of biochemical and immunohistochemical methods using monoclonal antireceptor antibodies. Arch Pathol Lab Med 1985;109: 716-21.

34 Nicholson RI, Bouzubar N, Walker KJ, McClelland R, Dixon AR, Robertson JF, et al. Hormone sensitivity in breast cancer: influence of heterogeneity of oestrogen receptor expression and cell proliferation. Eur $\mathcal{f}$ Cancer 1991;27:908-13.

35 McClelland RA, Wilson D, Leake R, Finlay P, Nicholson RI. A multicentre study into the reliability of steroid receptor immunocytochemical assay quantification. British Quality Control Group. Eur $\mathcal{F}$ Cancer 1991;27:711-15.

36 Snead DRJ, Bell JA, Dixon AR, Nicholson RI, Elston CW, Blamey RW, et al. Methodology of immunohistological detection of oestrogen receptor in human breast carcinoma in formalin-fixed, paraffin-embedded tissue: a comparison with frozen section methodology. Histopathology 1993;23: 233-8.

37 Shi RR, Key ME, Lalra KL. Antigen retrieval in formalinfixed, paraffin-embedded tissues, an enhancement method for immunohistochemical staining based on microwave oven heating of tissue sections. $\mathcal{F}$ Histochem Cytochem 1991; 39:741-8.

38 Graham DM, Jin L, Lloyd RV. Detection of estrogen receptor in paraffin-embedded sections of breast carcinoma by immunohistochemistry and in situ hybridization. $\mathrm{Am}$ f Surg Pathol 1991;15:475-85.

39 Koji T, Brenner RM. Localization of estrogen receptor messenger ribonucleic acid in rhesus monkey uterus by nonradioactive in situ hybridization with digoxigenin labelled oligodeoxynucleotides. Endocrinology 1993;132: 382-92.

40 Forsyth IA. The mammary gland. Clin Endocrinol Metab 1991;5:809-32.

41 Walker KJ, McClelland RA, Candlish W, Blamey RW, Nicholson RI. Heterogeneity of oestrogen receptor expression in normal and malignant breast tissue. Eur $\mathcal{F}$ Cancer 1992;28:34-7.

42 Nicholson RI. Why ER level may not reflect endocrine responsiveness in breast cancer. Rev Endocrinol Rel Cancer 1992;40:25-8.

43 Markopoulos C, Berger U, Wilson P, Gazet JC, Coombes RC. Oestrogen receptor content of normal breast cells and breast carcinomas throughout the menstrual cycle. BMF 1988;296:1349-51.

44 Battersby S, Robertson BJ, Anderson TJ, King RJ, McPherson K. Influence of menstrual cycle, parity and oral contraceptive use on steroid hormone receptors in normal breast. Br f Cancer 1992;65:601-7.

45 Toth J, De Sombre ER, Greene GL. Immunohistochemical analysis of estrogen and progesterone receptors in benign breast diseases. Zentralbl Pathol 1991;137:227-32.

46 Campbell FC, Blamey RW, Elston CW, Nicholson RI, Griffiths K, Haybittle JL. Oestrogen-receptor status and sites of metastasis in breast cancer. $B r \mathcal{F}$ Cancer 1981;44: 456-9.

47 McClelland RA, Berger U, Miller LS, Powles TJ, Coombes RC. Immunocytochemical assay for oestrogen receptors $\mathrm{RC}$. Immunocytochemical assay for oestrogen receptors in patients with breast cancer: relationship to a biochemical assay and

48 Ravdin PM, Green S, Dorr TM, McGuire WL, Fabian C, Pugh RP, et al. Prognostic significance of progesterone receptor levels in estrogen receptor-positive patients with metastatic breast cancer treated with tamoxifen: results of a prospective Southwest Oncology Group study. 7 Clin Oncol 1992;10:1284-91.

49 Howell A, Harland RN, Barnes DM, Baildam AD, Wilkinson MJ, Hayward E, et al. Endocrine therapy for advinson MJ, Hayward E, et al. Endocrine therapy for adeffect of tamoxifen upon concentrations of progesterone effect of tamoxifen upon concentrations of progesterone
receptor and subsequent response to treatment. Cancer receptor and subse

50 Blamey RW, Bishop HM, Blake JR, Doyle PJ, Elston CW, Haybittle $J \mathrm{~L}$, et al. Relationship between primary breast tumor receptor status and patient survival. Cancer 1980; 46:2765-9.

51 Early Breast Cancer Trialists' Group. Systemic treatment of early breast cancer by hormonal, cytotoxic, or immune therapy. 133 randomised trials involving 31,000 recurrences and 24,000 deaths among 75,000 women. Lancet 1992;339:1-15.

52 Henry JA, Angus B, Horne $\mathrm{CH}$. Oestrogen receptor and oestrogen regulated proteins in human breast cancer: a review. Keio $¥ \mathrm{Med}$ 1989;38:241-61.

53 Nicholson RI, McClelland RA, Gee JMW, Manning DL, Cannon P, Robertson JFR, et al. Transforming growth
factor-alpha and endocrine sensitivity in breast cancer. Cancer Res 1994;54:1684-9.
54 Nicholson RI, McClelland RA, Finlay P, Eaton CL, Gullick WJ, Dixon AR, et al. Relationship between EGF-R, cerbB-2 protein expression and $\mathrm{Ki}-67$ immunostaining in breast cancer and hormone insensitivity. Eur $\mathcal{f}$ Cancer 1993;29:1018-23.

55 Nicholson RI, McClelland RA, Gee JMW, Manning DL, Cannon P, Robertson JFR, et al. Epidermal growth factor receptor expression in breast cancer: association with response to endocrine therapy. Breast Cancer Res Treat 1994; 29:117-25.

56 Rio MC, Chambon P. The pS2 gene, mRNA, and protein: a potential marker for human breast cancer. Cancer Cells 1990;2:269-74.

57 Manning DL, McClelland RA, Gee JM, Chan CM, Green $\mathrm{CD}$, Blamey RW, et al. The role of four oestrogen-responsive genes, pLIV1, pS2, pSYD3 and pSYD8, in predicting responsiveness to endocrine therapy in primary breast cancer. Eur $\mathcal{f}$ Cancer 1993;29:1462-8.

58 Rochefort H. Cathepsin D in breast cancer. Breast Cancer Res Treat 1990;16:3-13.

59 Sacks NP, Smith K, Norman AP, Greenall M, LeJeune S, Harris AL. Cathepsin D levels in primary breast cancers: relationship with epidermal growth factor receptor, oestrogen receptor and axillary nodal status. Eur $\mathcal{F}$ Cancer 1993;29:426-8.

60 Manning DL, Robertson JFR, Ellis IO, Elston CW, McClelland RA, Gee JMW, et al. Oestrogen regulated genes in breast cancer: association of pLIV1 with lymph node involvement. Eur $\mathcal{F}$ Cancer 1994;30:675-8.

61 Fuqua SA, Falette NF, McGuire WL. Sensitive detection of estrogen receptor RNA by polymerase chain reaction assay. F Natl Cancer Inst 1990;82:858-61.

62 McGuire WL, Chamness GC, Fuqua SA. Abnormal estrogen receptor in clinical breast cancer. $\mathcal{F}$ Steroid Biochem Mol Biol 1992;43:243-7.

63 Karnik PS, Kulkarni S, Liu XP, Budd GT, Bukowski RM. Estrogen receptor mutations in tamoxifen-resistant breast cancer. Cancer Res 1994;54:349-53.

64 Fuqua SA, Fitzgerald SD, Allred DC, Elledge RM, Nawaz Z, McDonnell DP, et al. Inhibition of estrogen receptor action by a naturally occurring variant in human breast action by a naturally occurring vari
tumors. Cancer Res 1992;52:483-6.

65 Press MF, Nousek-Goebl NA, Bur M, Greene GL. Estrogen receptor localization in the female genital tract. $A m \mathcal{F}$ Pathol 1986;123:280-92.

66 Kauppila AJ, Isotalo HE, Kivinen ST, Vihko RK. Prediction of clinical outcome with estrogen and progestin receptor concentrations and their relationships to clinical and histopathological variables in endometrial cancer. Cancer Res 1986;46:5380-4.

67 Lindahl B, Alm P, Ferno M, Grundsell H, Norgren A, Trope C. Relapse of endometrial carcinoma related to steroid receptor concentration, staging, histologic grading and myometrial invasion. Anticancer Res 1986;6:1317-20.

68 Ingram SS, Rosenman J, Heath R, Morgan TM, Moore D, Varia $M$. The predictive value of progesterone receptor levels in endometrial cancer. Int $\mathcal{F}$ Radiat Oncol Biol Phys 1989;17:21-7.

69 Chambers JT, MacLusky N, Eisenfield A, Kohorn EI, Lawrence $R$, Schwartz PE. Estrogen and progestin receptor levels as prognosticators for survival in endometrial cancer. Gynecol Oncol 1988;31:65-81.

70 Palmer DC, Muir IM, Alexander AI, Cauchi M, Bennett RC, Quinn MA. The prognostic importance of steroid receptors in endometrial carcinoma. Obstet Gynecol 1988; 72:388-93.

71 Creasman WT. Prognostic significance of hormone receptors in endometrial cancer. Cancer 1993;71:1467-70.

72 Bonkhoff $\mathrm{H}$, Remberger K. Widespread distribution of nuclear androgen receptors in the basal cell layer of the normal and hyperplastic human prostate. Virch Arch A Pathol Histopathol 1993;422:35-8.

73 Miyamoto KK, McSherry SA, Dent GA, Sar M, Wilson EM, French FS, et al. Immunohistochemistry of the androgen receptor in human benign and malignant prostate tissue. f Urol 1993;149:1015-19.

74 Wernert N, Gerdes J, Loy V, Seitz G, Scherr O, Dhom G. Investigations of the estrogen (ER-ICA test) and the progesterone receptor in the prostate and prostatic carcinoma on an immunohistochemical basis. Virchows Arch A Pathol Histopathol 1988;412:387-91.

75 Masai M, Sumiya H, Akimoto S, Yatani R, Chang CS, Liao SS, et al. Immunohistochemical study of androgen receptor in benign hyperplastic and cancerous human prostates. Prostate 1990;17:293-300.

76 Sadi MV, Walsh PC, Barrack ER. Immunohistochemical study of androgen receptors in metastatic prostate cancer. Comparison of receptor content and response to hormonal therapy. Cancer 1991;67:3057-64.

77 Suzuki H, Sato N, Watabe Y, Masai M, Seino S, Shimazaki J. Androgen receptor gene mutations in human prostate cancer. $\mathcal{F}$ Steroid Biochem Mol Biol 1993;46:759-65.

78 Schoenberg MP, Hakimi JM, Wang S, Bova GS, Epstein JI, Fischbeck KH, et al. Microsatellite mutation (CAG $24 \rightarrow 18$ ) in the androgen receptor gene in human prostate cancer. Biochem Biophys Res Commun 1994;198:74-80.

79 Kokontis J, Ito K, Hiipakka RA, Liao S. Expression and function of normal and LNCaP androgen receptors in androgen-insensitive human prostatic cancer cells. Altered hormone and antihormone specificity in gene transactivation. Receptor 1991b;1:271-9.

80 Hutter RV. The role of the pathologist in breast cancer management. Cancer 1990;66:1363-72. 